\title{
Deciphering and Reversing Immunosuppressive Cells in the Treatment of Hepatocellular Carcinoma
}

\author{
Su Jong Yu ${ }^{1^{*}}$, Tim F. Greten ${ }^{2,3^{*}}$ \\ 'Department of Internal Medicine and Liver Research Institute, Seoul National University College of Medicine, Seoul, Korea, ${ }^{2}$ Gastroin- \\ testinal Malignancy Section, Thoracic and Gastrointestinal Oncology Branch, Center for Cancer Research, National Cancer Institute, \\ National Institutes of Health, Bethesda; ${ }^{3} \mathrm{NCI}$ CCR Liver Cancer Program, Bethesda, USA
}

Received Oct. 1, 2019

Revised Nov. 6, 2019

Accepted Nov. 10, 2019
Use of immune checkpoint inhibitors (ICls) in hepatocellular carcinoma (HCC) has been partially successful. However, most HCC patients do not respond to immunotherapy. HCC has been shown to induce several immune suppressor mechanisms in patients. These suppressor mechanisms include involvement of myeloid-derived suppressor cells, regulatory T-cells, functionally impaired dendritic cells (DCs), neutrophils, monocytes, and tumor associated macrophages. The accumulation of immunosuppressive cells may lead to an immunosuppressive tumor microenvironment as well as the dense fibrotic stroma which may contribute to immune tolerance. Our laboratory has been investigating different cellular mechanisms of immune suppression in HCC patients. In vitro as well as in vivo studies have demonstrated that abrogation of the suppressor cells enhances or unmasks tumor-specific antitumor immune responses. Two or three effective systemic therapies including ICls and/or molecular targeted therapies and the addition of innovative combination therapies targeting immune suppressor cells may lead to increased immune recognition with a greater tumor response. We reviewed the literature for the latest research on immune suppressor cells in HCC, and here we provide a comprehensive summary of the recent studies in this field. (J Liver Cancer 2020;20:1-16)

Keywords: Hepatocellular carcinoma; Immunotherapy; Immune checkpoint inhibitors; Immune suppression

\section{BACKGROUND}

Studies in the last decade have increasingly recognized the anti-tumor function of the immune system as a fundamental

\section{Corresponding author : Tim F. Greten}

Gastrointestinal Malignancy Section, Thoracic and Gastrointestinal Oncology Branch, Center for Cancer Research, National Cancer Institute, National Institutes of Health, 10 Center Dr, Bethesda, MD 20892, USA Tel. +1-301-451-4723, Fax. +1-301-480-8780

E-mail; tim.greten@nih.gov

https://orcid.org/0000-0002-0806-2535

* S. J. Yu and T. F. Greten were responsible for the acquisition and interpretation of the data and drafting of the manuscript. principle of the malignant process as well as a new target for cancer treatment. While many immune modulating therapies are of significant scientific and clinical interest, immune checkpoint inhibitors (ICIs) have shown impressive clinical efficacy. Currently, there are two classes of ICIs receiving significant clinical attention. The first class includes inhibitors of the cytotoxic T-lymphocyte-associated protein 4 (CTLA-4) ligand. The second class includes inhibitors of the programmed cell death protein 1 (PD-1). With the recent FDA approval of nivolumab and pembolizumab for the treatment of hepatocellular carcinoma (HCC) patients who have been previously treated with sorafenib, immunotherapy has be- 
come a treatment option for patients with HCC despite recent results from two negative trials. We and other research groups have previously demonstrated that spontaneous tumor-specific immune responses occur frequently in HCC patients. Both humoral and cellular tumor-specific immune responses to HCC has been reported. ${ }^{1-5}$ Immune-based approaches for treatment of HCC are aimed primarily at immune effector cell functions rather than the tumor immune microenvironment, which hosts different immune cells with immunosuppressive functions. The tumor microenvironment (TME) has also been shown to influence the response to immunotherapies, including ICIs. Accumulation of immunosuppressive cells, such as myeloid-derived suppressor cells (MDSCs), regulatory T-cells (Tregs), tumor-associated macrophages (TAMs) and neutrophils have been shown to limit the response to immunotherapies and also correlate with a poor prognosis. ${ }^{6-8}$

Tumors are broadly classified into categories of infiltratedexcluded, infiltrated-inflamed, or infiltrated with tertiary lymphocyte structures. ${ }^{9}$ Infiltrated-inflamed tumors are the most susceptible to immune checkpoint therapy. Treatment with antibodies against CTLA-4 lead to a T-cell-enriched tumor phenotype. ${ }^{10}$ An extensive analysis of 10,000 tumors, comprising 33 diverse cancer types (including HCC), showed six immune subsets of cancers. ${ }^{11}$ Most HCCs were characterized as lymphocyte depleted; tumors of high-macrophage or inflammatory subtypes (high ratio of Th1 to Th2 cells) had a large number of Th17 cells and a balanced ratio of macrophages to lymphocytes. ${ }^{12}$ Technologies such as RNA sequencing combined with CIBERSORT ${ }^{13}$ and XCell, ${ }^{14}$ in combination with mass spectrometric analysis of single cells, ${ }^{15}$ allow for multiplex high-dimensional analysis of immune cell populations in tumors.

These studies also suggest that tumor-specific cellular immune responses can be potentially overshadowed by different suppressor mechanisms, disabling effective anti-tumor immunity. In this article, we review and summarize the current knowledge on cellular suppressor mechanisms in patients with HCC.

\section{IMMUNOSUPPRESSIVE CELLS}

\section{Myeloid-derived suppressor cells}

MDSCs are a mixture of immature myeloid cells, immature granulocytes, monocytes, macrophages, DCs, and myeloid progenitor cells generated in the context of cancer. ${ }^{16-19}$ Pathological activation is the result of persistent stimulation of the myeloid compartment with relatively low-strength signals coming from the tumors or sites of chronic inflammation. Myeloid cells generated under these conditions are poorly phagocytic, produce high levels of reactive oxygen and nitrogen species, and predominantly anti-inflammatory cytokines. ${ }^{20}$ As a result, these cells are not able to effectively perform the normal functions of myeloid cells and acquire potent immune-suppressive potential. Although MDSCs suppress diverse immune functions, their main immunosuppressive actions are exerted through the inhibition of T-cells and natural killer (NK) cells and induction of Tregs. The major factors involved in MDSC-mediated immunosuppression include arginase-1 (ARG1), inducible nitric oxide synthase (iNOS), reactive oxygen species (ROS), transforming growth factor-beta (TGF- $\beta$ ), interleukin-10 (IL-10), COX2, and indoleamine 2,3-dioxygenase (IDO). ${ }^{21,22}$ ARG1 depletes L-arginine and leads to cell cycle arrest in the tumor-infiltrating $\mathrm{T}$ cells at G0-G1 phase. Depleted L-arginine increases NO production by iNOS, resulting in increased ROS production; all result in the down-regulation or desensitization of the $\mathrm{T}$ cell receptor and induction of T-cell anergy. IDO degrades Ltryptophan and leads to the suppression of T- and NK cells, and activation of Tregs. ${ }^{22}$ Studies have also suggested that the immunosuppressive mechanisms of MDSCs may vary at different sites. In peripheral lymphoid structures, polymorphonuclear (PMN)-MDSCs (CD11b $\left.{ }^{+} \mathrm{Ly}_{6 \mathrm{G}^{+}} \mathrm{Ly} \mathrm{C}^{\mathrm{lo}}\right)$ have a high level of ROS production and suppress T-cells function in an antigen-specific manner. In contrast, monocytic (M)-MDSCs (CD11b ${ }^{+}$Ly6G $^{-}$Ly6C $^{\text {hi }}$ ) suppress not only antigen-specific but also nonspecific $\mathrm{T}$-cell responses by expressing various factors such as ARG1, NO, TGF- $\beta$, and IL- $10 .^{23}$ In TME, because of hypoxia, ROS levels in PMN-MDSCs are substantially reduced; however, the levels of ARG1 and other factors 
responsible for nonspecific T-cell suppression show an increase. ${ }^{21}$ Additionally, MDSCs influence TME by inducing tumor angiogenesis through the production of several angiogenic factors and vascular-modulating enzymes. ${ }^{24}$ For example, bombina variegata peptide 8 (Bv8, a homolog of endocrine-gland-derived vascular endothelial growth factor [VEGF]), produced by MDSCs through granulocyte colonystimulating factor (G-CSF)-dependent signal transducer and activator of transcription 3 (STAT3) signaling, was demonstrated to promote angiogenesis and hematopoietic cell mobilization. ${ }^{25}$ Accumulation of MDSC in TME was associated with tumor refractoriness to anti-VEGF treatment; anti-GCSF therapy or anti-Bv8 therapy could enhance the responsiveness of anti-VEGF treatment. ${ }^{26,27}$ Moreover, matrix metalloproteinase-9 (MMP-9)-expressing CD11 ${ }^{+}$myelomonocytic cells have been shown to be critical for the formation of tumor vasculature. Tumor growth could be inhibited in MMP9 knockout mice or by the deletion of MMP-9 in CD11 ${ }^{+} \mathrm{Grl}^{+}$ MDSCs. ${ }^{28,29}$ In addition, MDSCs could acquire endothelial cell properties in TME and directly get incorporated into the tumor endothelium. ${ }^{29}$

Recent studies have investigated the roles of MDSCs in the efficacy of ICIs in mouse HCC models. Chiu et. al studied multiple orthotopic mouse HCC models and found tumor hypoxia induced the ectoenzyme, ectonucleoside triphosphate diphosphohydrolase 2 (ENTPD2), by stabilizing hypoxia-inducible factor-1 (HIF-1) in cancer cells. ENTPD2 supported the maintenance of MDSCs, and targeting ENTPD2 inhibited tumor growth and enhanced the efficacy of PD-1/CTLA-4 blockade. ${ }^{30}$ Zhou et al. demonstrated that the overexpression of cell cycle-related kinase (CCRK), a cyclin dependent kinase family member, increased MDSC accumulation and T-cell suppression in liver-specific CCRK inducible transgenic mice. ${ }^{31}$ Targeting CCRK or downstream IL-6 signaling reduced tumor-infiltration of MDSCs and increased intra-tumoral immunity via interferon (IFN) $-\gamma^{+}$tumor necrosis factor- $\alpha(\text { TNF- } \alpha)^{+} \mathrm{CD}^{+}$T-cells. As CCRK targeting drugs are not on the market, it may be easier to block IL- 6 and combine this treatment with ICIs. However, more preclinical studies are needed to confirm this combination strategy. ${ }^{32}$
In human peripheral blood mononuclear cell (PBMC), the equivalent to PMN-MDSC are defined as $\mathrm{CD} 11 \mathrm{~b}^{+} \mathrm{CD} 14^{-}$ $\mathrm{CD}_{15} 5^{+}$or $\mathrm{CD} 11 \mathrm{~b}^{+} \mathrm{CD} 14^{-} \mathrm{CD} 66 \mathrm{~b}^{+}$and M-MDSC as

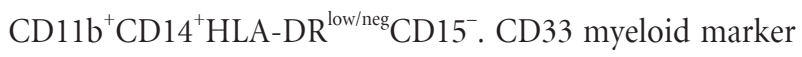
can be used instead of CD11b because very few $\mathrm{CD}_{1} 5^{+}$cells are $\mathrm{CD} 11 \mathrm{~b}^{-23} .^{23}$ Recently, lectin-type oxidized LDL receptor-1 (LOX-1) has been identified as a new marker for PMN-MDSCs in humans, further facilitating the discrimination of human PMN-MDSCs from mature neutrophils. ${ }^{33}$ We have identified human monocytic CD $14^{+} \mathrm{HLA}^{-D R^{\text {low/neg }}}$ MDSCs in patients with HCC and described an increase in the frequency of CD $14^{+}$HLA-DR ${ }^{\text {low/neg }}$ MDSCs in peripheral blood and ascites in these patients. ${ }^{34}$ We showed that CD $14^{+}$HLA-DR ${ }^{\text {low }}$ ${ }^{\text {neg }}$ MDSCs failed to induce proliferative T-cell responses and did not mature into DCs in vitro. Apart from their ability to suppress nonspecific T-cell responses, MDSCs also masked alfa-fetoprotein (AFP)-specific T-cell responses. ${ }^{34}$ In addition, we showed that human MDSCs induced a T regulatory phenotype when co-cultured with $\mathrm{CD} 4{ }^{+}$T-cells. ${ }^{34}$ Interestingly, while MDSCs induced forkhead or winged helix family of transcription factor P3 (FoxP3) ${ }^{+}$Tregs, CD14 ${ }^{+} \mathrm{HLA}_{-} \mathrm{DR}^{+}$ cells induced a different $\mathrm{T}$ helper subtype, Th17 cells. ${ }^{35}$

To better understand the biology and the clinical relevance of human MDSCs, we further examined the interaction between MDSCs and other immune cells like NK and cytokineinduced killer (CIK) cells. NK cells represent an important cell type in the context of HCC. NK cells are impaired in function in HCC patients. ${ }^{36}$ We have previously demonstrated that MDSCs are potent suppressors of NK cells in patients with HCC. ${ }^{37}$ In addition, we have demonstrated that adoptive cell transfer of CIK cells into tumor bearing mice induced inflammatory mediators (e.g., CX3CL1, IL-13) in the TME and an increase of tumor infiltrating MDSCs leading to impaired anti-tumor activity in two different murine HCC tumor models. ${ }^{38}$ MDSCs efficiently suppressed the cytotoxic activity of CIK cells in vitro. Tadalafil treatment, a phosphodiesterase-5 (PDE5) inhibitor, has previously been shown to reverse MDSC suppressor function via ARG1 and iNOS blockade. ${ }^{39,40}$ We showed that systemic treatment with PDE5 inhibitor prevented MDSC accumulation in the TME upon murine CIK cell therapy and increased its anti-tumor effica- 
cy. Similar results were observed when human CIK cells were tested in vitro in the presence of $\mathrm{CD} 14^{+} \mathrm{HLA}-\mathrm{DR}^{\text {low/neg }} \mathrm{MD}$ SCs. Treatment of MDSCs with a PDE5 inhibitor suppressed MDSCs suppressor function and enhanced CIK activity against human HCC cell lines in vitro. ${ }^{38}$

\section{Regulatory T-cells}

$\mathrm{CD} 4^{+} \mathrm{CD} 25^{+}$Tregs are a minor but functionally unique population of T-cells which maintain immune homeostasis in immune tolerance and the control of autoimmunity. In vitro Tregs can inhibit immune responses mediated by both $\mathrm{CD}^{+}$and $\mathrm{CD}^{+}$effector T-cells by a contact-dependent and cytokine-independent mechanism. ${ }^{41-43}$ However, the mechanism of immune suppression is much more complex in vivo, ${ }^{16,44}$ and includes events such as IL-2 depletion by CD25 (IL-2 receptor), competition between CD28 and CTLA-4, CTLA-4-mediated down-regulation of CD80 and CD86, ${ }^{45}$ and expression of TGF- $\beta$ and IL- $10 .^{46}$ The recruitment of Tregs in HCC occurs via the CCR6-CCL20 axis $^{47}$ and CCL22 induction by tumor cell-secreted IL- $1 \alpha{ }^{48}$ FoxP3 is not only essential for development of Tregs but also remains the best marker to identify these cells. However, several studies have shown that activation of human non-Tregs can also lead to expression of FoxP3 in vitro, suggesting that this marker needs to be used with caution. ${ }^{17}$ Alternatively, it has been suggested that analysis of FoxP3 methylation status can be used to determine the presence of Tregs in humans. ${ }^{49}$ In addition, FoxP3 up-regulation and conversion of $\mathrm{CD}^{+}{ }^{+} \mathrm{T}$-cells into Tregs may be fostered by poor stimulation of naive $\mathrm{CD} 4^{+} \mathrm{T}$-cells combined with TGF- $\beta$ signaling by tumor cells. Previous studies have demonstrated the pivotal role of Tregs in tumor immunology and their ability to suppress anti-tumor immune responses. Accordingly, targeting Tregs has been shown to boost anti-tumor immunity. Involvement of $\mathrm{CD} 4^{+} \mathrm{CD} 25^{+}$Tregs in human cancer has been observed in peripheral blood and tumor tissues from patients with several types of cancer. ${ }^{50-52}$ We and others have been able to demonstrate that Tregs are increased in peripheral blood and tumor-infiltrating lymphocytes of patients with HCC. . $53,54^{-54}$ While initial investigations only demonstrated an increase in
Tregs frequencies in patients with HCC, follow-up studies have explored a potential correlation with disease progression and patients' outcomes. ${ }^{55,56}$ One study demonstrated that an up-regulation of Tregs was associated with a significantly reduced $\mathrm{CD}^{+}{ }^{+} \mathrm{T}$-cell infiltration of tumors. ${ }^{57}$ Recently, deep single-cell RNA sequencing on 5,063 single T-cells isolated from peripheral blood, tumor, and adjacent normal tissues from six HCC patients revealed that exhausted $\mathrm{CD} 8^{+} \mathrm{T}$ cells and Tregs were preferentially enriched and potentially clonally expanded. ${ }^{58}$ Layilin was up-regulated on Tregs and repressed the $\mathrm{CD} 8{ }^{+} \mathrm{T}$-cell functions in vitro. ${ }^{58} \mathrm{~A}$ correlation between poor survival and an increase in Tregs was also shown in the same report and validated by other studies. ${ }^{59,60}$ Finally, patients with advanced HCC had a higher percentage of intra-hepatic $\mathrm{CD} 8^{+} \mathrm{FoxP}^{+}$Tregs than did patients with early disease, suggesting that $\mathrm{CD}^{+}{ }^{+} \mathrm{FoxP}^{+}{ }^{+}$Tregs also represent another immune escape mechanism. ${ }^{61}$

As Tregs are increased in patients with HCC and correlate with a worse outcome, we examined whether Tregs also suppress tumor-specific T-cell responses. We showed that in $v i$ tro depletion of Tregs unmasks AFP-specific immune responses in PBMC isolated from patients with HCC. Based on this in vitro observation, we performed a clinical trial targeting Tregs in patients with HCC. Patients were treated with low-dose cyclophosphamide, which had been shown in mice to target Tregs. While the number of patients treated in this study was too small to draw any definite conclusions, the results demonstrated that the frequency of Tregs in peripheral blood can be temporarily reduced by low-dose cyclophosphamide treatment. ${ }^{44,62}$

\section{Tumor-associated macrophages}

Macrophages are a major component of the leukocyte infiltrate that is present, to a widely varying extent, in all tumors. ${ }^{63}$ Dissection of the roles of TAMs in tumor progression has elucidated the contributions of other inflammatory cells and mediators, such as inflammatory cytokines. In fact, TAMs have a dominant role as orchestrators of cancer-related inflammation.

Liver macrophages consist of ontogenically distinct popu- 
lations, namely, the resident Kupffer cells (KCs) and monocyte-derived macrophages (Mo-Mfs). KCs are self-renewing and nonmigratory phagocytes. In the TME, chemokines secreted by malignant and stromal cells recruit bone marrowderived Ly6C $\mathrm{C}^{\text {hi }}$ monocytes. These infiltrating monocytes subsequently give rise to a large number of Mo-Mfs, which further differentiate and can replace and acquire a phenotype that is almost indistinguishable from resident KCs under specific circumstances. ${ }^{64-69}$ After infiltration, Mo-Mfs seem to acquire the ability to proliferate. ${ }^{66}$ It is however, unclear if they are able to sustain the number of TAMs in tumor lesions independently when not being continually recruited. As a result of this continuous transition, the compartment of hepatic myeloid cells consists of subtypes of macrophages in a different stages of differentiation. Each state is associated with stereotypic alterations in cell surface marker expression, which can be used for identification. In many studies, CD68 is used as an indicator for tissue macrophages; however, this marker is not sufficiently specific. More recently, two markers were proposed to distinguish between Mo-Mfs and KCs. Clec4F and Tim4 are expressed by KCs but absent from infiltrating Mo-Mfs. ${ }^{70}$ Additionally, these markers can be used to discriminate between KCs and recently differentiated Mo-KCs as the latter do not express Tim4 during the first week, postdifferentiation. However, with time, Mo-KCs will also gain expression of Tim $4{ }^{66,67}$ It is not clear to what extent TAMs are derived from tissue-resident liver cells or only represent infiltrating bone marrow derived Mo-Mfs. Although KCs were initially thought to be only involved in antitumor immunity, there is substantial evidence suggesting that KCs are part of the TAM population and enhance tumor progression. ${ }^{71-74}$

Defining TAMs as a single population has limitations due to an overgeneralized definition of TAMs and the need for further subdivision according to their polarization. Macrophages can be classified into a classically activated (pro-inflammatory) M1 state triggered by interferon- $\gamma$ and/or lipopolysaccharide, or an alternatively activated (antiinflammatory) M2 state induced by IL- $4 .^{70}$ This pro- and anti-inflammatory paradigm leads to the confusing assumption that in an inflammation-related tumor, an M2 phenotype would be beneficial. However, during tumor progres- sion in HCC, macrophage function is skewed from M1 to M2 phenotype ${ }^{75,76}$ The polarization of macrophages not only depends on the disease stage but also differs between tumoral nodules or within different areas of the same tumor. In human HCC, for example, most of the perivascular macrophages are more M1-like compared to the M2-like TAM in hypoxic areas. ${ }^{6477} \mathrm{M} 2$ macrophages are characterized by producing high levels of IL-10 that induce Tregs expansion and impairs NK cell activation. ${ }^{78}$ In addition, TAM promote tumor angiogenesis and dissemination. ${ }^{79,80} \mathrm{~A}$ distinct subset of monocytes expressing TIE2 with enhanced pro-angiogenic properties has been described in peripheral blood and in tumor infiltrate. ${ }^{81-83}$

\section{Tumor-associated neutrophils}

Tumor-associated neutrophils (TANs) have been proposed to support tumor development by promoting cellular transformation, tumor progression, and antitumor immunity. Proinflammatory cytokine IL-17 is a critical mediator for the recruitment of neutrophils in the TME. ${ }^{84}$ TANs may influence tumor progression through recruiting macrophages and Tregs to the TME, the paracrine release of cytokines and chemokines with protumor or antitumor functions, depending on the TME. ${ }^{85}$ CCL2 and CCL17 are the most highly expressed chemokines in TANs and peripheral blood neutrophils activated by HCC cells. ${ }^{85}$ CCL2 and CCL17 recruited $\mathrm{CCR} 2^{+}$macrophages and $\mathrm{CCR} 4^{+}$Tregs in vitro, respectively. ${ }^{85}$ TANs infiltration has been described to positively correlate with angiogenesis progression at the tumor-invading edge of HCC patients and to be a poor prognostic factor. ${ }^{86,87}$

\section{Monocytes}

The role of monocytes in the TME of HCC has been thoroughly studied by Zheng's research group. It has been shown that expression of PD-L1 on the surface of monocytes and macrophages in the peritumoral stroma suppresses T-cell responses. ${ }^{88}$ They also demonstrated that monocytes not only suppressed T-cell function directly but also induced Th17 cells ${ }^{89}$ as well as IL-17-secreting effector $\mathrm{CD}^{+}{ }^{+} \mathrm{T}$-cells (Tc17 cells). ${ }^{90}$ 


\section{Th17 Cells}

It has been shown that Th17 cells are associated with poor outcomes in HCC. ${ }^{91}$ We have shown an increase in the frequency of Th17 cells in peripheral blood and Th17-related cytokines (IL-17, IL-23) in tumor supernatants from HCC patients. This observation prompted us to investigate whether Th17 cells have an effect on $\mathrm{CD}^{+}{ }^{+} \mathrm{T}$-cell function. In vitro studies demonstrated that Th17 cells inhibit IFN- $\gamma$ production and proliferation by $\mathrm{CD} 8^{+} \mathrm{T}$-cells. Further analysis revealed that only the $\mathrm{CCR} 4^{+} \mathrm{CCR} 6^{+}$subpopulation of Th17 cells were responsible for this effect, which prompted us to further examine CCR $4^{+} \mathrm{CCR} 6{ }^{+}$Th 17 cell populations in HCC patients. Interestingly, we found only an increase in $\mathrm{CCR}^{+} \mathrm{CCR}^{+}{ }^{+} \mathrm{Th} 17$ cells in peripheral blood from patients with HCC but not in CCR $4{ }^{\text {neg }} \mathrm{CCR}^{+}{ }^{+}$Th 17 cells. ${ }^{92}$ CCR $4^{+} \mathrm{CCR} 6^{+} \mathrm{CD} 4^{+} \mathrm{T}$-cells demonstrated a marked suppression of $\mathrm{CD} 8^{+} \mathrm{T}$-cell responses in contrast to $\mathrm{CCR} 4^{\text {neg }} \mathrm{CCR} 6^{+} \mathrm{CD} 4^{+}$ T-cells.

\section{Hepatic sinusoidal endothelial \& stellate cells}

In the liver, it has been reported that sinusoidal endothelial cells induce immune tolerance against $\mathrm{CD}^{+} \mathrm{T}$-cells against tumor-associated antigens (TAAs) released from cancer cells that have undergone apoptosis. ${ }^{93}$ In addition, sinusoidal endothelial cells have been reported to contribute to the immunosuppressive environment in the liver by inducing Tregs or PD-L1 through membrane-bound TGF- $\beta{ }^{94}$ Furthermore, liver stellate cells are present in the liver. In HCC patients in which the cells are activated, an immunosuppressive environment for the tumor is induced and has been reported to have a poor prognosis. ${ }^{95}$ Activated stellate cells have been reported to induce monocytes to an immunosuppressive phenotype, MDSCs, T-cell dysfunction, and apoptosis via PDL1 expression. ${ }^{96}$

\section{STRATEGIES FOR TARGETING IMMUNO- SUPPRESSIVE CELLS (TABLE 1)}

\section{MDSCs: MDSCs inhibition could be a use- ful adjunct to immune therapies and can be placed into five categories ${ }^{97}$}

1) Deactivation of MDSC by PDE5 inhibitors such as sildenafil and tadalafil via the degradation of cyclic guanosine monophosphate (cGMP) leading to reduction in ARG1 and NOS2 expression. ${ }^{40}$ STAT3 is a critical transcription factor for immunosuppressive activity and proliferation of MDSCs. A STAT3 oligonucleotide inhibitor, danvatirsen (AZD9150), was tested in a phase I/Ib clinical trial of patients with advanced/metastatic HCC (NCT01839604). Thirty-nine patients received the study agent in the escalation or expansion cohort. Only one patient in the escalation cohort had a partial response. The most common adverse events were transaminase elevation and thrombocytopenia. Histone deacetylase (HDAC) inhibitors may suppress MDSC function by reducing ARG1, iNOS, and COX-2 levels. ${ }^{98}$ Several clinical trials have tested various HDAC inhibitors in HCC. ${ }^{99,100} \mathrm{Al}-$ though these agents were generally tolerated, the effect of such therapy on MDSCs was not evaluated.

2) Differentiation of MDSC into mature cells by using alltrans-retinoic acid (ATRA) ${ }^{101}$ or a derivative of vitamin $\mathrm{A}^{102}$

3) Blocking development of MDSC by N-Bisphosphonate via decreased prenylation of MMP9 which may influence MDSC generation/function by cleaving c-kit, which is believed to play a role in MDSC mobilization from the bone marrow niche. ${ }^{103}$

4) Depletion of MDSC by cytotoxic agents like gemcitabine, ${ }^{104}$ cisplatin, paclitaxel, or 5-fluorouracil (5-FU) or heat shock protein 90 (HSP90) inhibitor, 17-dimethylaminoethylamino-17-demethoxygeldanamycin. A preclinical study demonstrated that cabozantinib which showed significant survival benefits compared to a placebo in patients with HCC who had been previously treated with sorafenib ${ }^{105}$ reduced intra-tumoral PMN-MDSCs and enhanced the therapeutic effect of ICIs in a prostate cancer model. ${ }^{106} \mathrm{~A}$ recent preclinical study demonstrated that MDSCs could be selec- 
tively targeted by tumor necrosis factor-related apoptosis-inducing ligand (TRAIL) receptor 2 (TRAIL-R2/DR5) agonist. ${ }^{107}$ A phase I clinical trial testing the agonistic TRAIL-R2 antibody DS-8273a in patients with advanced cancer, including HCC, found that DS-8273a eliminated MDSCs without affecting mature myeloid or lymphoid cells; the decrease in MDSCs was associated with progression-free survival. ${ }^{108}$

5) Blockade of MDSC trafficking into TME is crucial for their main immunosuppressive function to be manifested. Therefore, inhibiting chemokine receptors may reduce the number of MDSCs in TME. Chemokine receptor CCR2 and the interaction of its ligand CCL2 are required not only for the recruitment of M-MDSCs and TAMs but also for their suppressive function. ${ }^{109,110}$ CCR5 is another chemokine receptor that is expressed in many immune cells. The CCR5CCR5 ligand axis was found to be critical for the mobilization of PMN-MDSCs. ${ }^{111}$ However, there has been no clinical development of inhibitors of these chemokine receptors in HCC. Recently, our group demonstrated that tadalafil, a PDE5 inhibitor prevented MDSC accumulation in the TME by decreasing inflammatory cytokines/chemokines (e.g., CX3CL1, IL-13), both in subcutaneous and orthotopic murine HCC models. ${ }^{38}$

\section{Tregs: Methods to target Tregs include de- pletion of Tregs, blocking immune checkpoint receptors, recruitment of Tregs, and treatment of cells with inhibitory cytokines}

1) Depletion of Tregs: CD25 is a well-known Treg cell marker and was found to be preferentially expressed in tumors in vivo, ${ }^{112}$ and depletion of $\mathrm{CD} 4{ }^{+} \mathrm{CD} 25^{+}$Tregs using anti-CD25 monoclonal antibodies was capable of enhancing CCL21-mediated antitumor immunity in a mouse HCC

Table 1. Strategies for targeting immunosuppressive cells

\begin{tabular}{|c|c|c|c|}
\hline Characteristic & MDSCs & Tregs & TAMs \\
\hline Deactivation & $\begin{array}{l}\text { - PDE5 inhibitor } \\
\text { - STAT3 oligonucleotide inhibitor } \\
\text { - HDAC inhibitor }\end{array}$ & & \\
\hline Differentiation & $\begin{array}{l}\text { - ATRA } \\
\text { - Derivative of vitamin A }\end{array}$ & & \\
\hline Blocking development & - N-Bisphosphonate & & \\
\hline Depletion & $\begin{array}{l}\text { - Cytotoxic agents (gemcitabine, } \\
\text { cisplatin, paclitaxel, or 5-FU or } \\
\text { HSP90 inhibitor, 17-DMAG) }\end{array}$ & - Fc-optimized anti-CD25 Ab & $\begin{array}{l}\text { - Liposome-encapsulated } \\
\text { clodronate }\end{array}$ \\
\hline Blockade of trafficking & - PDE5 inhibitor & - Anti-CCR4 Ab & $\begin{array}{l}\text { - } \text { Anti-CCR2 Ab } \\
\text { - } C C L 2 \text { neutralizing Ab }\end{array}$ \\
\hline Blocking Inhibitory Cytokines & & $\begin{array}{l}\text { - Neutralization of IL-35 or } \\
\text { Treg-specific deletion of IL-35 }\end{array}$ & \\
\hline Reprogramming Polarization & & & $\begin{array}{l}\text { - Baicalin, a natural flavonoid } \\
\text { - CSF-1R inhibitor }\end{array}$ \\
\hline Blocking the downstream effect & & & - Anti-IL-6 receptor Ab (tocilizumab) \\
\hline $\begin{array}{l}\text { New systemic therapies } \\
\text { (TKIs or ICls) }\end{array}$ & $\begin{array}{l}\text { - } \text { Cabozantinib } \\
\text { - Agonistic TRAlL-R2 Ab }\end{array}$ & $\begin{array}{l}\text { - } \text { Anti-PD-1 Ab } \\
\text { - Anti-CTLA-4 Ab } \\
\text { - Anti-GITR Ab } \\
\text { - Anti-OX40 Ab }\end{array}$ & $\begin{array}{l}\text { - Lenvatinib } \\
\text { - VEGF inhibitor (bevacizumab) \& } \\
\text { anti-PD-L1 Ab (atezolizumab) }\end{array}$ \\
\hline
\end{tabular}

MDSCs, myeloid-derived suppressor cells; Treg, regulatory T-cells; TAM, tumor associated macrophages; PDE, phosphodiesterase; STAT, signal transducer and activator of transcription; HDAC, histone deacetylase; ATRA, all-trans-retinoic acid; FU, fluorouracil; HSP, heat shock protein; DMAG, 17-dimethylaminoethylamino-17-demethoxygeldanamycin; TKI, tyrosine kinase inhibitor; ICI, immune checkpoint inhibitor; TRAIL, tumor necrosis factor-related apoptosis-inducing ligand; IL, interleukin; PD, programmed cell death protein; CTLA, cytotoxic T-lymphocyte-associated protein; GITR, glucocorticoid-induced TNFR family related gene; CCR, cell cycle-related kinase; CCL, C-C motif chemokine ligand; CSF, stimulating factor; VEGF, vascular endothelial growth factor; TNFR, tumor necrosis factor receptor. 
model. ${ }^{113}$ Treatment with Fc-optimized anti-CD25 antibody resulted in the effective depletion of Tregs and an increase in the effector T-cells (Teff)-to-Tregs ratio, leading to tumor regression and increased survival. ${ }^{112}$

2) Immune Checkpoint Inhibitors: Mechanistically, antiCTLA-4 was first thought to prevent Tregs from intercepting costimulatory signals from DCs, resulting in DC-induced Teff cell activation and proliferation. Ipilimumab and tremelimumab induce significant activation and expansion of Teff and $\mathrm{CD}^{+}{ }^{\mathrm{T}}$-cells. ${ }^{114-118}$ The effect of ipilimumab was recently substantiated by depleting Tregs via antibody-dependent cell-mediated cytotoxicity (ADCC). ${ }^{119}$ However, tremelimumab, which does not have ADCC activity, had a similar therapeutic effect, suggesting that Treg depletion may not be the main mechanism of action of ipilimumab. Another Tregspecific marker glucocorticoid-induced TNFR family related gene (GITR) is also a target for tumor infiltrating Tregs. Unlike in Tregs, GITR acts as a costimulatory molecule in Teff cells, suggesting a beneficial effect in cancer therapy. In animal models, anti-GITR antibody induced antitumor activity by increasing Teff cells. ${ }^{120}$ Combined treatment with antiGITR and anti-PD-1 antibodies further enhanced antitumor activity in some HCC patients. ${ }^{121}$ OX40, a member of the TNF receptor family, has a mechanism of action similar to that of GITR; that is, anti-OX40 antibody stimulates Teff cells but inhibits Tregs. High-OX40 expression was associated with the activation of multiple immunosuppressive pathways and poor prognosis in HCC patients. ${ }^{122}$ Anti-OX40 antibody enhanced $\mathrm{CD}^{+} \mathrm{T}$-cell-mediated antitumor immunity in animal models of cancer. ${ }^{123}$ Antibodies against GITR and OX40 are now in clinical trials. ${ }^{124}$ Combining Treg cell depletion with ICIs resulted in a synergistic effect in an animal model of Claudin-low breast cancer, a subtype of triple-negative breast cancer. ${ }^{125}$ Tregs depletion and ICIs each had little effect on tumor growth, whereas their combination greatly reduced tumor burden. ${ }^{125}$

3) Blocking Tregs Recruitment: Infiltration of Tregs into tumors is a prerequisite for their activity. Tregs express a variety of chemokine receptors, including CCR4, CCR5, CCR6, CCR7, CCR10, CXCR3, and CXCR4, and migrate efficiently in response to tumor-derived chemokines. ${ }^{126-128}$ CCR4 is preferentially expressed on tumor infiltrating Tregs rather than on Teff cells, ${ }^{129}$ with the CCL17/22-CCR4 axis playing an important role in multiple cancers including HCC. ${ }^{126-128,130}$ A monoclonal antibody targeting CCR4 has shown promising results, effectively depleting Tregs, both in vitro and in clinical trials in human cancer patients. ${ }^{128,131} \mathrm{CXCR}^{+}$Tregs selectively accumulate in ovarian cancer and block the interactions between CXCR3 and its ligands CXCL9, CXCL10, and CXCL11, thereby suppressing tumor growth. ${ }^{132}$

4) Blocking Inhibitory Cytokines: Because the TME is rich in immunosuppressive cytokines that strengthen the activity of Tregs, neutralizing these cytokines may reestablish effective antitumor immunity. Genetic ablation or blocking of IL10 or TGF- $\beta$ signaling results in tumor regression. ${ }^{133-136}$ Overexpression of IL-35 was correlated with $\mathrm{CD} 39^{+} \mathrm{FoxP}^{+}$ Tregs infiltration and HCC aggressiveness and was an independent prognostic factor. ${ }^{137}$ In addition, neutralization of IL-35 or Treg-specific deletion of IL-35 was found to enhance antitumor T-cell responses and reduce tumor growth in various mouse tumor models. ${ }^{138}$ Interestingly, IL-35 produced by Tregs promoted the expression of several inhibitory molecules, including PD-1, TIM-3, and LAG-3, leading to Tcell exhaustion. The higher numbers of IL-35-expressing Tregs present in tumors than in the spleen can be exploited for tumor-specific blockade of Treg cell function without affecting Treg function in general. ${ }^{138}$

\section{TAMs: Current approaches for TAMs-targeted therapy are aimed at decreasing the popu- lation of TAMs by eliminating TAMs present in the tumor, blocking recruitment of bone marrow-derived monocytes, and/or repro- gramming TAM polarization to anti-tumoral behavior}

1) Depletion of TAMs: Administration of liposome-encapsulated clodronate partially depleted TAMs, resulting in reduced tumor growth in a murine Hepal-6 cell-transplanted tumor model. Not only was the total amount of TAMs reduced but, in addition, the number of M2-like TAMs in tumors of liposome-treated mice was found to be significantly 
lower than that in tumors of untreated mice. In contrast, the number of M1 TAMs was not significantly affected. According to the authors, these results suggest that after depleting the majority of TAMs, the remaining macrophages might undergo a phenotypical transition. ${ }^{139}$

2) Inhibiting Recruitment of Monocytes: The chemokine C-C motif ligand 2 (CCL2, also referred to as monocyte chemoattractant protein 1 or MCP-1) and the corresponding CCL2-CCR2 signaling axis are important targets to inhibit the recruitment of monocytes. Treatment with a CCR2 antagonist inhibited HCC tumor growth in different murine models. The therapy reduced the infiltration of blood Ly$6 C^{\text {high }}$ inflammatory monocytes, subsequently lowered the number of TAMs in the HCC lesions, and reduced most of the cytokines or chemokines produced by M2-like TAMs (CD206-positive cells). Moreover, the reduced number of remaining TAMs shifted towards the M1 phenotype. The CCR2 antagonist also supported tumor-infiltrated $\mathrm{CD}^{+}{ }^{+}$cells by blocking TAM-mediated immunosuppression. ${ }^{140,141}$ In addition, Teng et al. showed the tumor-inhibiting effect of a CCL2 neutralizing antibody by reducing the population of inflammatory myeloid cells in an HCC mouse model. ${ }^{142}$

3) Reprogramming Polarization of TAMs: Oral administration of baicalin, a natural flavonoid present in several medicinal plants, inhibited growth of HCC lesions in an orthotopic mouse model by initiating TAM reprogramming to an M1-like phenotype with proinflammatory cytokine production. Coculturing of HCC cells with baicalin-treated macrophages resulted in reduced proliferation and motility in vitro. ${ }^{143}$ Colony-stimulating factor-1 (CSF-1) and its receptor, CSF-1R, regulate the differentiation and function of macrophages. CSF-1R blockade by a competitive inhibitor signifi-

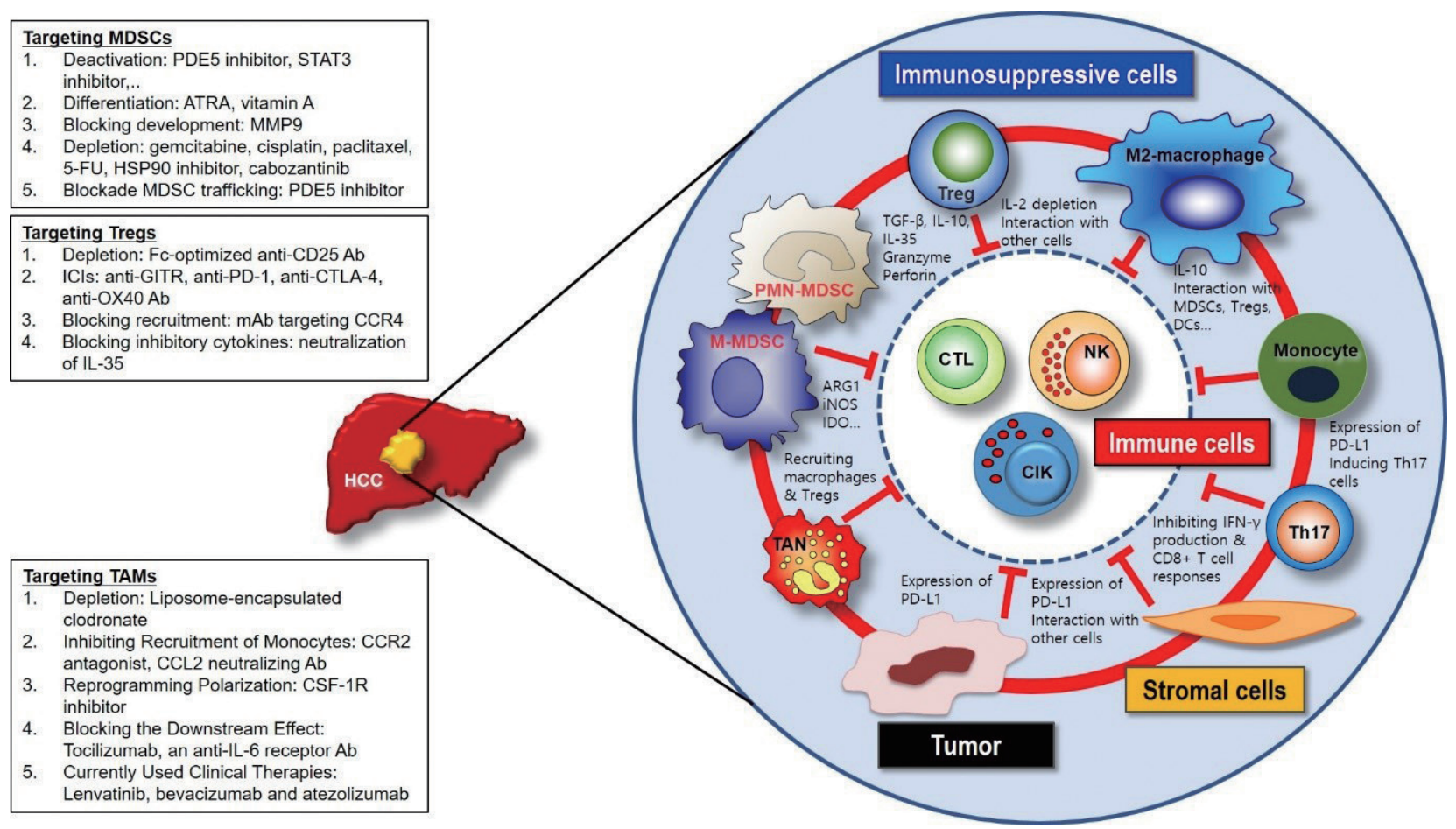

Figure 1. Cross-talks among immune cells, immunosuppressive cells, stromal cells, and tumor cells in the tumor microenvironment of hepatocellular carcinoma. PDE, phosphodiesterase; STAT, signal transducer and activator of transcription; ATRA, all-trans-retinoic acid; MMP, matrix metalloproteinase; FU, fluorouracil; HSP, heat shock protein; MDSCs, myeloid-derived suppressor cells; GITR, glucocorticoid-induced TNFR family related gene; PD, programmed cell death protein; CTLA, cytotoxic T-lymphocyte-associated protein; CCR, cell cycle-related kinase; IL, interleukin; TAM, tumor associated macrophages; CCL, C-C motif chemokine ligand; CSF, stimulating factor; Treg, regulatory T-cells; PMN, polymorphonuclear; TAN, tumor-associated neutrophils; TGF, transforming growth factor; ARG, arginase; iNOS, inducible nitric oxide synthase; IDO, indoleamine 2,3-dioxygenase; DC, dendritic cells; NK, natural killer; CIK, cytokine-induced killer; TNFR, tumor necrosis factor receptor. 
cantly delayed tumor growth in murine xenograft models. The compound inhibited the proliferation of macrophages in vitro; however, macrophage infiltration was not decreased in vivo. Thus, the effect is not mediated by TAM depletion. Gene expression profiling showed that TAMs in the treated tumors are polarized towards an M1-like phenotype. ${ }^{144}$

4) Blocking the Downstream Effect of TAMs: TAMs represent a major paracrine IL-6 source during HCC progression, and autocrine IL-6 contributed significantly to HCC initiation from HCC progenitor cells. Blockade of IL-6 signaling using tocilizumab, an anti-IL-6 receptor antibody approved by the FDA for the treatment of rheumatoid arthritis, was able to inhibit TAM-stimulated activity of cancer stem cells in vitro and in vivo. ${ }^{145}$

5) Therapy Affecting TAMs with Currently Used Clinical Therapies: Lenvatinib has been reported to enhance the therapeutic effect of ICIs by reducing TAMs locally at the tumor and enhancing antitumor IFN signal. ${ }^{146}$ In fact, also in human clinical trials, the efficacy of the combination therapy of lenvatinib and pembrolizumab has been reported. ${ }^{147}$ The efficacy of the combination of VEGF inhibitor (bevacizumab) and anti-PD-L1 antibody (atezolizumab) for HCC has been reported. ${ }^{147}$ Because VEGF increases TAMs and Tregs and enhances the expression of immune checkpoint molecules including PD-1 molecules of CD8 ${ }^{+}$T-cells, ${ }^{148,149}$ combination therapy of VEGF inhibitors and anti-PD-1 antibodies makes sense. It is expected that multiplex immunotherapy combining such molecular targeted drugs with immunotherapy will be increasingly developed in the future.

\section{CONCLUSIONS}

HCC has unique immune evasive microenvironment, in which multiple cellular and molecular immune evasive mechanisms could be targeted by immunotherapy. Targeting immune checkpoint molecules such as CTLA-4, PD-1, and PD-L1 has opened new opportunities for cancer treatment with successful responsive outcomes. Emerging evidences in HCC patients suggest that modulation of the immune checkpoint pathways could lead promising clinical responses with manageable toxicity profile. However, we believe that it will be important in the future to test treatment modalities which will target immunosuppressive cell populations, especially in trials which aim to enhance anti-tumor immune responses (Fig. 1). Future approaches for HCC immunotherapy are to establish novel strategies rationally combined with other current or future treatment options in order to maximize the antitumor efficacy.

\section{ACKNOWLEDGEMENT}

This research was supported in part by the Intramural Research Program of the NIH, NCI and in part by the Scientific Research Fund of the Korean Liver Cancer Study Group 2015.

\section{Conflicts of Interest}

The authors have no conflicts to disclose.

\section{REFERENCES}

1. Korangy F, Ormandy LA, Bleck JS, Klempnauer J, Wilkens L, Manns $M P$, et al. Spontaneous tumor-specific humoral and cellular immune responses to NY-ESO-1 in hepatocellular carcinoma. Clin Cancer Res 2004;10:4332-4341.

2. Mizukoshi E, Nakamoto Y, Arai K, Yamashita T, Sakai A, Sakai Y, et al. Comparative analysis of various tumor-associated antigenspecific t-cell responses in patients with hepatocellular carcinoma. Hepatology 2011;53:1206-1216.

3. Behboudi S, Pereira SP. Alpha-fetoprotein specific CD4 and CD8 Tcell responses in patients with hepatocellular carcinoma. World J Hepatol 2010;2:256-260.

4. Behboudi S, Boswell S, Williams R. Cell-mediated immune responses to alpha-fetoprotein and other antigens in hepatocellular carcinoma. Liver Int 2010;30:521-526.

5. Zhang HG, Chen HS, Peng JR, Shang XY, Zhang J, Xing Q, et al. Specific CD8(+ )T-cell responses to HLA-A2 restricted MAGE-A3 p271-279 peptide in hepatocellular carcinoma patients without vaccination. Cancer Immunol Immunother 2007;56:1945-1954.

6. Arihara F, Mizukoshi E, Kitahara M, Takata Y, Arai K, Yamashita T, et al. Increase in CD14+HLA-DR -/low myeloid-derived suppressor cells in hepatocellular carcinoma patients and its impact on prognosis. Cancer Immunol Immunother 2013;62:1421-1430.

7. Hato T, Goyal L, Greten TF, Duda DG, Zhu AX. Immune checkpoint blockade in hepatocellular carcinoma: current progress and future directions. Hepatology 2014;60:1776-1782. 
8. Ormandy LA, Hillemann T, Wedemeyer H, Manns MP, Greten TF, Korangy F. Increased populations of regulatory T-cells in peripheral blood of patients with hepatocellular carcinoma. Cancer Res 2005;65:2457-2464.

9. Binnewies M, Roberts EW, Kersten K, Chan V, Fearon DF, Merad M, et al. Understanding the tumor immune microenvironment (TIME) for effective therapy. Nat Med 2018;24:541-550.

10. Duffy AG, Ulahannan SV, Makorova-Rusher O, Rahma O, Wedemeyer $H$, Pratt $D$, et al. Tremelimumab in combination with ablation in patients with advanced hepatocellular carcinoma. J Hepatol 2017;66:545-551.

11. Thorsson V, Gibbs DL, Brown SD, Wolf D, Bortone DS, Ou Yang TH, et al. The immune landscape of cancer. Immunity 2018;48:812830.e814.

12. Greten TF, Lai CW, Li G, Staveley-O'Carroll KF. Targeted and immune-based therapies for hepatocellular carcinoma. Gastroenterology 2019;156:510-524.

13. Newman AM, Liu CL, Green MR, Gentles AJ, Feng W, Xu Y, et al. Robust enumeration of cell subsets from tissue expression profiles. Nat Methods 2015;12:453-457.

14. Aran D, Hu Z, Butte AJ. xCell: digitally portraying the tissue cellular heterogeneity landscape. Genome Biol 2017;18:220.

15. Spitzer MH, Nolan GP. Mass cytometry: single cells, many features. Cell 2016;165:780-791.

16. von Boehmer H. Mechanisms of suppression by suppressor T-cells. Nat Immunol 2005;6:338-344.

17. Gavin MA, Torgerson TR, Houston E, DeRoos P, Ho WY, StrayPedersen $A$, et al. Single-cell analysis of normal and FOXP3mutant human T-cells: FOXP3 expression without regulatory T-cell development. Proc Natl Acad Sci U S A 2006;103:6659-6664.

18. Greten TF, Manns MP, Korangy F. Myeloid derived suppressor cells in human diseases. Int Immunopharmacol 2011;11:802-807.

19. Gabrilovich DI, Ostrand-Rosenberg S, Bronte V. Coordinated regulation of myeloid cells by tumours. Nat Rev Immunol 2012;12:253268.

20. Youn JI, Collazo M, Shalova IN, Biswas SK, Gabrilovich DI. Characterization of the nature of granulocytic myeloid-derived suppressor cells in tumor-bearing mice. J Leukoc Biol 2012;91:167-181.

21. Gabrilovich DI. Myeloid-derived suppressor cells. Cancer Immunol Res 2017;5:3-8.

22. Gabrilovich DI, Nagaraj S. Myeloid-derived suppressor cells as regulators of the immune system. Nat Rev Immunol 2009;9:162174.

23. Bronte V, Brandau S, Chen SH, Colombo MP, Frey AB, Greten $T F$, et al. Recommendations for myeloid-derived suppressor cell nomenclature and characterization standards. Nat Commun 2016;7:12150.

24. Murdoch C, Muthana M, Coffelt SB, Lewis CE. The role of myeloid cells in the promotion of tumour angiogenesis. Nat Rev Cancer 2008;8:618-631.

25. Qu X, Zhuang G, Yu L, Meng G, Ferrara N. Induction of Bv8 expression by granulocyte colony-stimulating factor in $\mathrm{CD} 11 \mathrm{~b}+\mathrm{Gr} 1+$ cells: key role of Stat3 signaling. J Biol Chem 2012;287:1957419584.

26. Shojaei F, Wu X, Malik AK, Zhong C, Baldwin ME, Schanz S, et al. Tumor refractoriness to anti-VEGF treatment is mediated by CD11b+Gr1+ myeloid cells. Nat Biotechnol 2007;25:911-920.

27. Shojaei F, Wu X, Qu X, Kowanetz M, Yu L, Tan M, et al. G-CSFinitiated myeloid cell mobilization and angiogenesis mediate tumor refractoriness to anti-VEGF therapy in mouse models. Proc Natl Acad Sci U S A 2009;106:6742-6747.

28. Ahn GO, Brown JM. Matrix metalloproteinase-9 is required for tumor vasculogenesis but not for angiogenesis: role of bone marrowderived myelomonocytic cells. Cancer Cell 2008;13:193-205.

29. Yang L, DeBusk LM, Fukuda K, Fingleton B, Green-Jarvis B, Shyr Y, et al. Expansion of myeloid immune suppressor $\mathrm{Gr}+\mathrm{CD} 11 \mathrm{~b}+$ cells in tumor-bearing host directly promotes tumor angiogenesis. Cancer Cell 2004;6:409-421.

30. Chiu DK, Tse AP, Xu IM, Di Cui J, Lai RK, Li LL, et al. Hypoxia inducible factor HIF-1 promotes myeloid-derived suppressor cells accumulation through ENTPD2/CD39L1 in hepatocellular carcinoma. Nat Commun 2017:8:517.

31. Zhou J, Liu M, Sun H, Feng Y, Xu L, Chan AWH, et al. Hepatomaintrinsic CCRK inhibition diminishes myeloid-derived suppressor cell immunosuppression and enhances immune-checkpoint blockade efficacy. Gut 2018;67:931-944.

32. Greten TF, Korangy F. CDK20 inhibition and immune checkpoint blockade: bringing cancer biology and tumour immunology together to develop novel treatment options for HCC. Gut 2018;67:783784.

33. Condamine T, Dominguez GA, Youn Jl, Kossenkov AV, Mony S, Alicea-Torres K, et al. Lectin-type oxidized LDL receptor-1 distinguishes population of human polymorphonuclear myeloid-derived suppressor cells in cancer patients. Sci Immunol 2016;1:aaf8943.

34. Hoechst B, Ormandy LA, Ballmaier $M$, Lehner F, Krüger C, Manns $M P$, et al. A new population of myeloid-derived suppressor cells in hepatocellular carcinoma patients induces CD4(+)CD25(+) Foxp3(+) T-cells. Gastroenterology 2008;135:234-243.

35. Hoechst B, Gamrekelashvili J, Manns MP, Greten TF, Korangy F. Plasticity of human Th17 cells and iTregs is orchestrated by different subsets of myeloid cells. Blood 2011;117:6532-6541.

36. Cai L, Zhang Z, Zhou L, Wang H, Fu J, Zhang S, et al. Functional impairment in circulating and intrahepatic NK cells and relative mechanism in hepatocellular carcinoma patients. Clin Immunol 2008;129:428-437.

37. Hoechst B, Voigtlaender T, Ormandy L, Gamrekelashvili J, Zhao 
F, Wedemeyer $\mathrm{H}$, et al. Myeloid derived suppressor cells inhibit natural killer cells in patients with hepatocellular carcinoma via the NKp30 receptor. Hepatology 2009;50:799-807.

38. Yu SJ, Ma C, Heinrich B, Brown ZJ, Sandhu M, Zhang Q, et al. Targeting the crosstalk between cytokine-induced killer cells and myeloid-derived suppressor cells in hepatocellular carcinoma. J Hepatol 2019;70:449-457.

39. Califano JA, Khan Z, Noonan KA, Rudraraju L, Zhang Z, Wang $H$, et al. Tadalafil augments tumor specific immunity in patients with head and neck squamous cell carcinoma. Clin Cancer Res 2015;21:30-38.

40. Serafini P, Meckel K, Kelso M, Noonan K, Califano J, Koch W, et al. Phosphodiesterase- 5 inhibition augments endogenous antitumor immunity by reducing myeloid-derived suppressor cell function. J Exp Med 2006;203:2691-2702.

41. Sakaguchi S, Yamaguchi T, Nomura T, Ono M. Regulatory T-cells and immune tolerance. Cell 2008;133:775-787.

42. Dieckmann D, Bruett $C H$, Ploettner $H$, Lutz MB, Schuler G. Human CD4(+)CD25(+) regulatory, contact-dependent T-cells induce interleukin 10-producing, contact-independent type 1-like regulatory Tcells [corrected]. J Exp Med 2002;196:247-253.

43. Shevach EM. CD4+ CD25+ suppressor T-cells: more questions than answers. Nat Rev Immunol 2002;2:389-400.

44. Chen ML, Pittet MJ, Gorelik L, Flavell RA, Weissleder R, von Boehmer $H$, et al. Regulatory T-cells suppress tumor-specific CD8 T-cell cytotoxicity through TGF-beta signals in vivo. Proc Natl Acad Sci U S A 2005;102:419-424.

45. Josefowicz SZ, Lu LF, Rudensky AY. Regulatory T-cells: mechanisms of differentiation and function. Annu Rev Immunol 2012;30:531564.

46. Sprinzl MF, Galle PR. Immune control in hepatocellular carcinoma development and progression: role of stromal cells. Semin Liver Dis 2014;34:376-388.

47. Chen KJ, Lin SZ, Zhou L, Xie HY, Zhou WH, Taki-Eldin A, et al. Selective recruitment of regulatory T-cell through CCR6-CCL20 in hepatocellular carcinoma fosters tumor progression and predicts poor prognosis. PLoS One 2011;6:e24671.

48. Wiedemann GM, Knott MM, Vetter VK, Rapp M, Haubner S, Fesseler J, et al. Cancer cell-derived IL-1a induces CCL22 and the recruitment of regulatory T-cells. Oncoimmunology 2016;5:e1175794.

49. Baron U, Floess S, Wieczorek G, Baumann K, Grützkau A, Dong J, et al. DNA demethylation in the human FOXP3 locus discriminates regulatory T-cells from activated FOXP3(+) conventional T-cells. Eur J Immunol 2007;37:2378-2389.

50. Curiel TJ, Coukos G, Zou L, Alvarez X, Cheng P, Mottram P, et al. Specific recruitment of regulatory $T$-cells in ovarian carcinoma fosters immune privilege and predicts reduced survival. Nat Med 2004;10:942-949.
51. Hiraoka N, Onozato K, Kosuge T, Hirohashi S. Prevalence of FOXP3 + regulatory T-cells increases during the progression of pancreatic ductal adenocarcinoma and its premalignant lesions. Clin Cancer Res 2006;12:5423-5434.

52. Badoual C, Hans S, Rodriguez J, Peyrard S, Klein C, Agueznay Nel H, et al. Prognostic value of tumor-infiltrating CD4+ T-cell subpopulations in head and neck cancers. Clin Cancer Res 2006;12:465472.

53. Unitt E, Rushbrook SM, Marshall A, Davies S, Gibbs P, Morris LS, et al. Compromised lymphocytes infiltrate hepatocellular carcinoma: the role of T-regulatory cells. Hepatology 2005;41:722-730.

54. Yang XH, Yamagiwa S, Ichida T, Matsuda Y, Sugahara S, Watanabe $\mathrm{H}$, et al. Increase of CD4+ CD25+ regulatory T-cells in the liver of patients with hepatocellular carcinoma. J Hepatol 2006;45:254262.

55. Shen X, Li N, Li H, Zhang T, Wang F, Li Q. Increased prevalence of regulatory $\mathrm{T}$-cells in the tumor microenvironment and its correlation with TNM stage of hepatocellular carcinoma. J Cancer Res Clin Oncol 2010;136:1745-1754.

56. Kobayashi N, Hiraoka N, Yamagami W, Ojima H, Kanai Y, Kosuge T, et al. FOXP3+ regulatory T-cells affect the development and progression of hepatocarcinogenesis. Clin Cancer Res 2007;13:902911.

57. Fu J, Xu D, Liu Z, Shi M, Zhao P, Fu B, et al. Increased regulatory Tcells correlate with CD8 T-cell impairment and poor survival in hepatocellular carcinoma patients. Gastroenterology 2007;132:23282339.

58. Zheng C, Zheng L, Yoo JK, Guo H, Zhang Y, Guo X, et al. Landscape of infiltrating $T$-cells in liver cancer revealed by single-cell sequencing. Cell 2017;169:1342-1356.e1316.

59. Gao Q, Qiu SJ, Fan J, Zhou J, Wang XY, Xiao YS, et al. Intratumoral balance of regulatory and cytotoxic T-cells is associated with prognosis of hepatocellular carcinoma after resection. J Clin Oncol 2007;25:2586-2593.

60. Zhou J, Ding T, Pan W, Zhu LY, Li L, Zheng L. Increased intratumoral regulatory T-cells are related to intratumoral macrophages and poor prognosis in hepatocellular carcinoma patients. Int J Cancer 2009;125:1640-1648.

61. Yang ZQ, Yang ZY, Zhang LD, Ping-Bie, Wang SG, Ma KS, et al. Increased liver-infiltrating CD8+FoxP3+ regulatory T-cells are associated with tumor stage in hepatocellular carcinoma patients. Hum Immunol 2010;71:1180-1186.

62. Greten TF, Ormandy LA, Fikuart A, Höchst B, Henschen S, Hörning $M$, et al. Low-dose cyclophosphamide treatment impairs regulatory T-cells and unmasks AFP-specific CD4+ T-cell responses in patients with advanced HCC. J Immunother 2010;33:211-218.

63. Noy R, Pollard JW. Tumor-associated macrophages: from mechanisms to therapy. Immunity 2014;41:49-61. 
64. Movahedi K, Van Ginderachter JA. The ontogeny and microenvironmental regulation of tumor-associated macrophages. Antioxid Redox Signal 2016;25:775-791.

65. Tacke F, Luedde T, Trautwein C. Inflammatory pathways in liver homeostasis and liver injury. Clin Rev Allergy Immunol 2009;36:412.

66. Scott CL, Zheng F, De Baetselier P, Martens L, Saeys Y, De Prijck S, et al. Bone marrow-derived monocytes give rise to self-renewing and fully differentiated Kupffer cells. Nat Commun 2016;7:10321.

67. Beattie L, Sawtell A, Mann J, Frame TCM, Teal B, de Labastida Rivera $F$, et al. Bone marrow-derived and resident liver macrophages display unique transcriptomic signatures but similar biological functions. J Hepatol 2016;65:758-768.

68. Sica A, Invernizzi P, Mantovani A. Macrophage plasticity and polarization in liver homeostasis and pathology. Hepatology 2014;59:2034-2042.

69. Devisscher L, Scott CL, Lefere S, Raevens S, Bogaerts E, Paridaens $A$, et al. Non-alcoholic steatohepatitis induces transient changes within the liver macrophage pool. Cell Immunol 2017;322:74-83.

70. Degroote H, Van Dierendonck A, Geerts A, Van Vlierberghe $H$, Devisscher L. Preclinical and clinical therapeutic strategies affecting tumor-associated macrophages in hepatocellular carcinoma. J Immunol Res 2018;2018:7819520.

71. Aravalli RN. Role of innate immunity in the development of hepatocellular carcinoma. World J Gastroenterol 2013;19:7500-7514.

72. Yang JD, Nakamura I, Roberts LR. The tumor microenvironment in hepatocellular carcinoma: current status and therapeutic targets. Semin Cancer Biol 2011;21:35-43.

73. Wu J, Li J, Salcedo R, Mivechi NF, Trinchieri G, Horuzsko A. The proinflammatory myeloid cell receptor TREM-1 controls Kupffer cell activation and development of hepatocellular carcinoma. Cancer Res 2012;72:3977-3986.

74. Wu K, Kryczek I, Chen L, Zou W, Welling TH. Kupffer cell suppression of CD8+ T-cells in human hepatocellular carcinoma is mediated by B7-H1/programmed death-1 interactions. Cancer Res 2009;69:8067-8075.

75. Prieto J, Melero I, Sangro B. Immunological landscape and immunotherapy of hepatocellular carcinoma. Nat Rev Gastroenterol Hepatol 2015;12:681-700.

76. Schreiber RD, Old LJ, Smyth MJ. Cancer immunoediting: integrating immunity's roles in cancer suppression and promotion. Science 2011;331:1565-1570.

77. Laoui D, Van Overmeire E, Movahedi K, Van den Bossche J, Schouppe $E$, Mommer $C$, et al. Mononuclear phagocyte heterogeneity in cancer: different subsets and activation states reaching out at the tumor site. Immunobiology 2011;216:1192-1202.

78. Ostrand-Rosenberg S, Sinha P, Beury DW, Clements VK. Cross-talk between myeloid-derived suppressor cells (MDSC), macrophages, and dendritic cells enhances tumor-induced immune suppression. Semin Cancer Biol 2012;22:275-281.

79. Lin EY, Li JF, Gnatovskiy L, Deng Y, Zhu L, Grzesik DA, et al. Macrophages regulate the angiogenic switch in a mouse model of breast cancer. Cancer Res 2006;66:11238-11246.

80. Qian B, Deng Y, Im JH, Muschel RJ, Zou Y, Li J, et al. A distinct macrophage population mediates metastatic breast cancer cell extravasation, establishment and growth. PLoS One 2009;4:e6562.

81. De Palma M, Venneri MA, Galli R, Sergi Sergi L, Politi LS, Sampaolesi $M$, et al. Tie2 identifies a hematopoietic lineage of proangiogenic monocytes required for tumor vessel formation and a mesenchymal population of pericyte progenitors. Cancer Cell 2005;8:211-226.

82. Murdoch C, Tazzyman S, Webster S, Lewis CE. Expression of Tie-2 by human monocytes and their responses to angiopoietin-2. J Immunol 2007;178:7405-7411.

83. Venneri MA, De Palma M, Ponzoni M, Pucci F, Scielzo C, Zonari $E$, et al. Identification of proangiogenic TIE2-expressing monocytes (TEMs) in human peripheral blood and cancer. Blood 2007; 109:5276-5285.

84. Zhao F, Korangy F, Greten TF. Cellular immune suppressor mechanisms in patients with hepatocellular carcinoma. Dig Dis 2012;30:477-482.

85. Zhou SL, Zhou ZJ, Hu ZQ, Huang XW, Wang Z, Chen EB, et al. Tumor-associated neutrophils recruit macrophages and T-regulatory cells to promote progression of hepatocellular carcinoma and resistance to sorafenib. Gastroenterology 2016;150:1646-1658.e1617.

86. Kuang DM, Zhao Q, Wu Y, Peng C, Wang J, Xu Z, et al. Peritumoral neutrophils link inflammatory response to disease progression by fostering angiogenesis in hepatocellular carcinoma. J Hepatol 2011;54:948-955.

87. Zhou SL, Dai Z, Zhou ZJ, Wang XY, Yang GH, Wang Z, et al. Overexpression of CXCL5 mediates neutrophil infiltration and indicates poor prognosis for hepatocellular carcinoma. Hepatology 2012;56:2242-2254.

88. Kuang DM, Zhao Q, Peng C, Xu J, Zhang JP, Wu C, et al. Activated monocytes in peritumoral stroma of hepatocellular carcinoma foster immune privilege and disease progression through PD-L1. J Exp Med 2009;206:1327-1337.

89. Kuang DM, Peng C, Zhao Q, Wu Y, Chen MS, Zheng L. Activated monocytes in peritumoral stroma of hepatocellular carcinoma promote expansion of memory T helper 17 cells. Hepatology 2010;51:154-164.

90. Kuang DM, Peng C, Zhao Q, Wu Y, Zhu LY, Wang J, et al. Tumoractivated monocytes promote expansion of IL-17-producing CD8+ T-cells in hepatocellular carcinoma patients. J Immunol 2010;185:1544-1549.

91. Zhang JP, Yan J, Xu J, Pang XH, Chen MS, Li L, et al. Increased 
intratumoral IL-17-producing cells correlate with poor survival in hepatocellular carcinoma patients. J Hepatol 2009;50:980-989.

92. Zhao F, Hoechst B, Gamrekelashvili J, Ormandy LA, Voigtländer T, Wedemeyer $\mathrm{H}$, et al. Human CCR4+ CCR6+ Th17 cells suppress autologous CD8+ T-cell responses. J Immunol 2012;188:60556062.

93. Höchst B, Schildberg FA, Böttcher J, Metzger C, Huss S, Türler A, et al. Liver sinusoidal endothelial cells contribute to CD8 T-cell tolerance toward circulating carcinoembryonic antigen in mice. Hepatology 2012;56:1924-1933.

94. Carambia A, Freund $B$, Schwinge $D$, Heine $M$, Laschtowitz $A$, Huber $S$, et al. TGF- $\beta$-dependent induction of $\mathrm{CD}^{+} \mathrm{CD} 25^{+} \mathrm{Foxp}^{+}$ Tregs by liver sinusoidal endothelial cells. J Hepatol 2014;61:594599.

95. Ji J, Eggert T, Budhu A, Forgues M, Takai A, Dang H, et al. Hepatic stellate cell and monocyte interaction contributes to poor prognosis in hepatocellular carcinoma. Hepatology 2015;62:481-495.

96. Yu MC, Chen CH, Liang X, Wang L, Gandhi CR, Fung JJ, et al. Inhibition of T-cell responses by hepatic stellate cells via B7-H1mediated T-cell apoptosis in mice. Hepatology 2004;40:1312-1321.

97. Wesolowski R, Markowitz J, Carson WE 3rd. Myeloid derived suppressor cells - a new therapeutic target in the treatment of cancer. J Immunother Cancer 2013;1:10.

98. Orillion A, Hashimoto A, Damayanti N, Shen L, Adelaiye-Ogala $R$, Arisa $S$, et al. Entinostat neutralizes myeloid-derived suppressor cells and enhances the antitumor effect of PD-1 inhibition in murine models of lung and renal cell carcinoma. Clin Cancer Res 2017;23:5187-5201.

99. Yeo W, Chung HC, Chan SL, Wang LZ, Lim R, Picus J, et al. Epigenetic therapy using belinostat for patients with unresectable hepatocellular carcinoma: a multicenter phase I/II study with biomarker and pharmacokinetic analysis of tumors from patients in the Mayo Phase II Consortium and the Cancer Therapeutics Research Group. J Clin Oncol 2012;30:3361-3367.

100. Bitzer M, Horger M, Giannini EG, Ganten TM, Wörns MA, Siveke $J T$, et al. Resminostat plus sorafenib as second-line therapy of advanced hepatocellular carcinoma - The SHELTER study. J Hepatol 2016;65:280-288.

101. Gabrilovich DI, Velders MP, Sotomayor EM, Kast WM. Mechanism of immune dysfunction in cancer mediated by immature Gr-1+ myeloid cells. J Immunol 2001;166:5398-5406.

102. Ugel S, Delpozzo F, Desantis G, Papalini F, Simonato F, Sonda N, et al. Therapeutic targeting of myeloid-derived suppressor cells. Curr Opin Pharmacol 2009;9:470-481.

103. Heissig B, Hattori K, Dias S, Friedrich M, Ferris B, Hackett NR, et al. Recruitment of stem and progenitor cells from the bone marrow niche requires MMP-9 mediated release of kit-ligand. Cell 2002;109:625-637.
104. Le HK, Graham L, Cha E, Morales JK, Manjili MH, Bear HD. Gemcitabine directly inhibits myeloid derived suppressor cells in BALB/ c mice bearing 4T1 mammary carcinoma and augments expansion of T-cells from tumor-bearing mice. Int Immunopharmacol 2009;9:900-909.

105. Abou-Alfa GK, Meyer T, Cheng AL, El-Khoueiry AB, Rimassa $L$, Ryoo BY, et al. Cabozantinib in patients with advanced and progressing hepatocellular carcinoma. N Engl J Med 2018;379:54-63.

106. Lu X, Horner JW, Paul E, Shang X, Troncoso P, Deng P, et al. Effective combinatorial immunotherapy for castration-resistant prostate cancer. Nature 2017;543:728-732.

107. Condamine T, Kumar V, Ramachandran IR, Youn JI, Celis E, Finnberg $N$, et al. ER stress regulates myeloid-derived suppressor cell fate through TRAIL-R-mediated apoptosis. J Clin Invest 2014;124:2626-2639.

108. Dominguez GA, Condamine T, Mony S, Hashimoto A, Wang F, Liu $\mathrm{Q}$, et al. Selective targeting of myeloid-derived suppressor cells in cancer patients using DS-8273a, an agonistic TRAIL-R2 antibody. Clin Cancer Res 2017;23:2942-2950.

109. Ugel S, De Sanctis F, Mandruzzato S, Bronte V. Tumor-induced myeloid deviation: when myeloid-derived suppressor cells meet tumor-associated macrophages. J Clin Invest 2015;125:3365-3376.

110. Lesokhin AM, Hohl TM, Kitano S, Cortez C, Hirschhorn-Cymerman $D$, Avogadri F, et al. Monocytic CCR2(+) myeloid-derived suppressor cells promote immune escape by limiting activated CD8 T-cell infiltration into the tumor microenvironment. Cancer Res 2012;72:876-886.

111. Karin $\mathrm{N}$, Razon $\mathrm{H}$. The role of CCR5 in directing the mobilization and biological function of CD11b(+)Gr1(+)Ly6C(low) polymorphonuclear myeloid cells in cancer. Cancer Immunol Immunother 2018;67:1949-1953.

112. Arce Vargas F, Furness AJS, Solomon I, Joshi K, Mekkaoui L, Lesko $\mathrm{MH}$, et al. Fc-Optimized Anti-CD25 depletes tumor-infiltrating regulatory T-cells and synergizes with PD-1 blockade to eradicate established tumors. Immunity 2017;46:577-586.

113. Zhou S, Chen L, Qin J, Li R, Tao H, Zhen Z, et al. Depletion of CD4+ CD25+ regulatory T-cells promotes CCL21-mediated antitumor immunity. PLoS One 2013;8:e73952.

114. Kavanagh B, O'Brien S, Lee D, Hou Y, Weinberg V, Rini B, et al. CTLA4 blockade expands FoxP3+ regulatory and activated effector CD4+ T-cells in a dose-dependent fashion. Blood 2008;112:11751183.

115. Maker AV, Attia P, Rosenberg SA. Analysis of the cellular mechanism of antitumor responses and autoimmunity in patients treated with CTLA-4 blockade. J Immunol 2005;175:7746-7754.

116. O'Mahony D, Morris JC, Quinn C, Gao W, Wilson WH, Gause B, et al. A pilot study of CTLA-4 blockade after cancer vaccine failure in patients with advanced malignancy. Clin Cancer Res 2007;13:958- 
964

117. Ralph C, Elkord E, Burt DJ, O'Dwyer JF, Austin EB, Stern PL, et al. Modulation of lymphocyte regulation for cancer therapy: a phase II trial of tremelimumab in advanced gastric and esophageal adenocarcinoma. Clin Cancer Res 2010;16:1662-1672.

118. Weber JS, Hamid O, Chasalow SD, Wu DY, Parker SM, Galbraith S, et al. Ipilimumab increases activated T-cells and enhances humoral immunity in patients with advanced melanoma. J Immunother 2012;35:89-97.

119. Simpson TR, Li F, Montalvo-Ortiz W, Sepulveda MA, Bergerhoff $K$, Arce $F$, et al. Fc-dependent depletion of tumor-infiltrating regulatory T-cells co-defines the efficacy of anti-CTLA-4 therapy against melanoma. J Exp Med 2013;210:1695-1710.

120. Ko K, Yamazaki S, Nakamura K, Nishioka T, Hirota K, Yamaguchi T, et al. Treatment of advanced tumors with agonistic anti-GITR mAb and its effects on tumor-infiltrating Foxp3+CD25+CD4+ regulatory T-cells. J Exp Med 2005;202:885-891.

121. van Beek AA, Zhou G, Doukas M, Boor PPC, Noordam L, Mancham $S$, et al. GITR ligation enhances functionality of tumorinfiltrating T-cells in hepatocellular carcinoma. Int J Cancer 2019;145:1111-1124.

122. Xie $K, X u L, W u H$, Liao $H$, Luo $L$, Liao $M$, et al. OX40 expression in hepatocellular carcinoma is associated with a distinct immune microenvironment, specific mutation signature, and poor prognosis. Oncoimmunology 2018;7:e1404214.

123. Piconese S, Valzasina B, Colombo MP. OX40 triggering blocks suppression by regulatory T-cells and facilitates tumor rejection. J Exp Med 2008;205:825-839.

124. Lesokhin AM, Callahan MK, Postow MA, Wolchok JD. On being less tolerant: enhanced cancer immunosurveillance enabled by targeting checkpoints and agonists of T-cell activation. Sci Transl Med 2015;7:280sr1.

125. Taylor NA, Vick SC, Iglesia MD, Brickey WJ, Midkiff BR, McKinnon $\mathrm{KP}$, et al. Treg depletion potentiates checkpoint inhibition in claudin-low breast cancer. J Clin Invest 2017;127:3472-3483.

126. Mailloux AW, Young MR. Regulatory T-cell trafficking: from thymic development to tumor-induced immune suppression. Crit Rev Immunol 2010;30:435-447.

127. Ondondo B, Jones E, Godkin A, Gallimore A. Home sweet home: the tumor microenvironment as a haven for regulatory T-cells. Front Immunol 2013;4:197.

128. Kurose K, Ohue Y, Sato E, Yamauchi A, Eikawa S, Isobe M, et al. Increase in activated treg in TIL in lung cancer and in vitro depletion of treg by ADCC using an antihuman CCR4 mAb (KM2760). J Thorac Oncol 2015;10:74-83.

129. Ishida $T$, Ishii $T$, Inagaki $A$, Yano $H$, Komatsu $H$, lida $S$, et al. Specific recruitment of $\mathrm{CC}$ chemokine receptor 4-positive regulatory $\mathrm{T}$ cells in Hodgkin lymphoma fosters immune privilege. Cancer Res
2006;66:5716-5722.

130. Cheng $X$, Wu H, Jin ZJ, Ma D, Yuen $S$, Jing $X Q$, et al. Up-regulation of chemokine receptor CCR4 is associated with human hepatocelIular carcinoma malignant behavior. Sci Rep 2017;7:12362.

131. Ishida T, Joh T, Uike N, Yamamoto K, Utsunomiya A, Yoshida S, et al. Defucosylated anti-CCR4 monoclonal antibody (KW-0761) for relapsed adult T-cell leukemia-lymphoma: a multicenter phase II study. J Clin Oncol 2012;30:837-842.

132. Redjimi N, Raffin C, Raimbaud I, Pignon P, Matsuzaki J, Odunsi $K$, et al. CXCR3+ T regulatory cells selectively accumulate in human ovarian carcinomas to limit type I immunity. Cancer Res 2012;72:4351-4360.

133. Muraoka RS, Dumont N, Ritter CA, Dugger TC, Brantley DM, Chen J, et al. Blockade of TGF-beta inhibits mammary tumor cell viability, migration, and metastases. J Clin Invest 2002;109:1551-1559.

134. Gorelik L, Flavell RA. Immune-mediated eradication of tumors through the blockade of transforming growth factor-beta signaling in T-cells. Nat Med 2001;7:1118-1122.

135. Sun Z, Fourcade J, Pagliano O, Chauvin JM, Sander C, Kirkwood JM, et al. IL10 and PD-1 Cooperate to Limit the Activity of TumorSpecific CD8+ T Cells. Cancer Res 2015;75:1635-1644.

136. Vicari AP, Chiodoni C, Vaure C, Aït-Yahia S, Dercamp C, Matsos F, et al. Reversal of tumor-induced dendritic cell paralysis by $\mathrm{CpG}$ immunostimulatory oligonucleotide and anti-interleukin 10 receptor antibody. J Exp Med 2002;196:541-549.

137. Fu YP, Yi Y, Cai XY, Sun J, Ni XC, He HW, et al. Overexpression of interleukin-35 associates with hepatocellular carcinoma aggressiveness and recurrence after curative resection. $\mathrm{Br} J$ Cancer 2016;114:767-776

138. Turnis ME, Sawant DV, Szymczak-Workman AL, Andrews LP, Delgoffe $\mathrm{GM}$, Yano $\mathrm{H}$, et al. Interleukin-35 limits anti-tumor immunity. Immunity 2016;44:316-329.

139. Wang B, Li Q, Qin L, Zhao S, Wang J, Chen X. Transition of tumorassociated macrophages from MHC class II(hi) to MHC class II(low) mediates tumor progression in mice. BMC Immunol 2011;12:43.

140. Li X, Yao W, Yuan Y, Chen P, Li B, Li J, et al. Targeting of tumourinfiltrating macrophages via CCL2/CCR2 signalling as a therapeutic strategy against hepatocellular carcinoma. Gut 2017;66:157-167.

141. Yao W, Ba Q, Li X, Li H, Zhang S, Yuan Y, et al. A natural CCR2 antagonist relieves tumor-associated macrophage-mediated immunosuppression to produce a therapeutic effect for liver cancer. EBioMedicine 2017;22:58-67.

142. Teng KY, Han J, Zhang X, Hsu SH, He S, Wani NA, et al. Blocking the CCL2-CCR2 axis using CCL2-neutralizing antibody is an effective therapy for hepatocellular cancer in a mouse model. Mol Cancer Ther 2017:16:312-322.

143. Tan HY, Wang N, Man K, Tsao SW, Che CM, Feng Y. Autophagyinduced RelB/p52 activation mediates tumour-associated macro- 
phage repolarisation and suppression of hepatocellular carcinoma by natural compound baicalin. Cell Death Dis 2015;6:e1942.

144. Ao JY, Zhu XD, Chai ZT, Cai H, Zhang YY, Zhang KZ, et al. Colonystimulating factor 1 receptor blockade inhibits tumor growth by altering the polarization of tumor-associated macrophages in hepatocellular carcinoma. Mol Cancer Ther 2017;16:1544-1554.

145. Wan S, Zhao E, Kryczek I, Vatan L, Sadovskaya A, Ludema G, et al. Tumor-associated macrophages produce interleukin 6 and signal via STAT3 to promote expansion of human hepatocellular carcinoma stem cells. Gastroenterology 2014;147:1393-1404.

146. Kato Y, Tabata K, Kimura T, Yachie-Kinoshita A, Ozawa Y, Yamada $K$, et al. Lenvatinib plus anti-PD-1 antibody combination treatment activates CD8 + T-cells through reduction of tumor-associated macrophage and activation of the interferon pathway. PLoS One 2019;14:e0212513.

147. Kudo M. Targeted and immune therapies for hepatocellular carcinoma: predictions for 2019 and beyond. World J Gastroenterol 2019;25:789-807.

148. Voron T, Colussi O, Marcheteau E, Pernot S, Nizard M, Pointet AL, et al. VEGF-A modulates expression of inhibitory checkpoints on CD8+ T-cells in tumors. J Exp Med 2015;212:139-148.

149. Lapeyre-Prost A, Terme M, Pernot S, Pointet AL, Voron T, Tartour $E$, et al. Immunomodulatory activity of VEGF in cancer. Int Rev Cell Mol Biol 2017;330:295-342. 